NORTH CAROLINA BANKING INSTITUTE

Volume 23 | Issue 1

Article 7

$3-1-2019$

\title{
The Legal Underpinnings of the Global Foreign Exchange Market
}

David T. Bloom

Follow this and additional works at: https://scholarship.law.unc.edu/ncbi

Part of the Banking and Finance Law Commons

\section{Recommended Citation}

David T. Bloom, The Legal Underpinnings of the Global Foreign Exchange Market, 23 N.C. BANking Inst. 27 (2019). Available at: https://scholarship.law.unc.edu/ncbi/vol23/iss1/7

This Article is brought to you for free and open access by Carolina Law Scholarship Repository. It has been accepted for inclusion in North Carolina Banking Institute by an authorized editor of Carolina Law Scholarship Repository. For more information, please contact law_repository@unc.edu. 


\title{
THE LEGAL UNDERPINNINGS OF THE GLOBAL FOREIGN EXCHANGE MARKET
}

\author{
DAVID T. BLOOM*
}

\section{INTRODUCTION}

The global foreign exchange market is the largest financial market in the world with average daily turnover in excess of $\$ 5$ trillion. ${ }^{1}$ The market is inexorably linked to international trade and investment activity as foreign exchange serves as the medium of exchange in global trade and cross-border investment. While the market originated with the Pharaohs in Egypt, the legal underpinnings of the modern global foreign exchange market have their origins in the post-war era when the Allied powers entered into the Bretton Woods Agreement in 1944 to promote global economic stability by creating a new global monetary system and removing impediments to trade. The Bretton Woods convention followed the inter-war period, during which the financial system had been turbulent with the collapse of the gold standard, the Great Depression, and the rise of protectionism. ${ }^{2}$ The Beggar-Thy-Neighbour policies adopted by governments to combat the Great Depression, such as high tariff barriers, competitive currency devaluations, and discriminatory trading blocs, contributed to the creation of an unstable international environment

\footnotetext{
* David T. Bloom is Senior Vice President and Deputy General Counsel - Wholesale of SunTrust Banks, Inc. Mr. Bloom has been an adviser to bank foreign exchange dealers for over twenty-five years and has participated in central bank sponsored foreign exchange market advisory groups including the Financial Markets Lawyers Group sponsored by the Federal Reserve Bank of New York, the Foreign Exchange Joint Standing Committee, Legal SubGroup sponsored by the Bank of England, and the European Financial Markets Lawyers Group sponsored by the European Central Bank. The views expressed in this article are those of Mr. Bloom and not those of the North Carolina Banking Institute Journal or SunTrust Banks, Inc. or its officers, directors or employees. Copyright (C) 2018 by David T. Bloom All rights reserved.

1. Bank for Int'l Settlements, Triennial Central Bank Survey: Foreign EXCHANGE TURNOVER IN APRIL 2016, at 3 (Sept. 2016), https://www.bis.org/publ/rpfx16fx.pdf.

2. U.S. Dep't of State, Office of the Historian, Protectionism in the Interwar PERIOD, https://history.state.gov/milestones/1921-1936/protectionism (last visited Jan. 15, 2019).
} 
without improving the economic situation. ${ }^{3}$ Bretton Woods created a system of fixed exchange rates based on the U.S. dollar, with the U.S. dollar being convertible into gold: a system which provided for the convertibility of currencies in support of free trade. Members of the Bretton Woods system agreed to avoid trade wars. For example, they would not lower their currencies strictly to increase trade. However, they could regulate their currencies under certain conditions by, for example, taking action if foreign capital flows began to destabilize their economies.

The International Monetary Fund ("IMF") and the World Bank were established at Bretton Woods. The IMF was charged with overseeing this system of fixed exchange rates centered on the U.S. dollar and gold, serving as a forum for consultation and cooperation, and a provider of short-term financial assistance to countries experiencing temporary deficits in their balance of payments. The World Bank was responsible for providing financial assistance for the reconstruction of war-ravaged nations and the economic development of less developed countries.

The fixed exchange rate system established at Bretton Woods endured for the better part of three decades; only after the international monetary crisis of August 1971, when President Richard Nixon suspended the dollar's convertibility into gold, did floating exchange rates become the norm for the major industrialized democracies. ${ }^{4}$ From that year forward, the world's major currencies were all floating, with no one currency having a fixed value, which led to the establishment of the global foreign exchange market as we know it today.

The legal framework has continued to evolve since the 1970s as the size and complexity of the global foreign exchange market has increased and new technologies have been adopted in transaction execution. At that time, the market was lightly regulated, principally by the prudential regulation of the major bank foreign exchange dealers via capital and risk management requirements. Since the 1970s, the development of industry best practices governing the market became prevalent. Different codes of conduct were developed or employed by foreign exchange committees and trade associations in different jurisdictions in order to promote best market practices, high standards of conduct, and professionalism, and encourage fair, liquid, transparent, and accessible

3. Id.

4. U.S. Dep't of State, Office of the Historian, Nixon and the End of the BRETTON WoOdS SysteM, 1971-1973, https://history.state.gov/milestones/1969-1976/nixonshock (last visited Jan. 13, 2019). 
foreign exchange markets. These codes typically had no statutory underpinnings but many have referred to legal requirements, ordinances, or regulations which are binding in applicable jurisdictions. In addition, these groups issued forms of master trading agreements establishing standard sets of contractual terms to govern foreign exchange transactions between market participants. These codes and master trading agreements are discussed in further detail in Parts IV and V of this article.

In the wake of the 2008 financial crisis and LIBOR manipulation enforcement actions in 2013, substantive regulations were introduced including those governing financial benchmarks such as spot foreign exchange benchmarks or "fixings." Moreover, the first global code of conduct was adopted following well-publicized multibillion dollar enforcement actions during 2013-2015 period involving incidents of market manipulation by major dealers in the foreign exchange markets.

In November 2008, the Group of 20 ("G20") met at the head of state and government level for the first time in Washington, D.C., at the peak of the global financial crisis, in order to restore global growth and achieve needed reforms in the world's financial systems. The G20 was initially established in 1999, consisting of the world's twenty leading industrialized and emerging economies. The group accounts for $85 \%$ of world Gross Domestic Product (“GDP”) and two-thirds of its population, including The People's Republic of China ("China"), France, Great Britain, Germany, the European Union ("EU"), the U.S., IMF and World Bank. ${ }^{5}$ Since many economists and politicians then called for a new Bretton Woods system to overhaul the world's financial structure, the meeting has been described as Bretton Woods II. ${ }^{6}$ Leaders set out a framework for preventing future financial crises while securing sustainable and balanced global growth and reforming the architecture of global economic governance. In particular, the Action Plan to Implement Principles for Reform annexed to the Declaration of the Summit on Financial Markets and the World Economy ("Action Plan") set forth five principles for reform: (a) strengthening transparency and accountability; (b) enhancing sound regulation; (c) promoting integrity in financial markets; (d)

5. Ministry of Foreign Affairs of Japan: Cabinet Pub. Relations Office of the GOV'T OF JAPAN, WHAT IS THE G20 SUMMIT?, https://g20.org/en/summit/about/ (last visited Jan. 15, 2019).

6. Joseph J. Norton, NIFA-II or 'Bretton Woods-II'?: The G-20 (Leaders) Summit Process on Managing Global Financial Markets and the World Economy - Quo Vadis?, 11 J. BANKING REG. 261-301, 262, 281 (2010), https://link.springer.com/content/pdf/10.1057\%2Fjbr.2010.17.pdf. 
reinforcing international cooperation; and (e) reforming international financial institutions. ${ }^{7}$

Pursuant to the Action Plan, the G20 launched a comprehensive program of international financial reforms comprised of four core elements:

- Making financial institutions more resilient through higher buffers, lower leverage, improved risk management and governance, and sound compensation practices;

- Ending "too-big-to-fail" by adopting requirements for higher loss absorbency of global systemically important financial institutions, by subjecting those institutions to more intensive supervision, and by establishing legal regimes and regulatory frameworks that allow their resolution in the event of failure without taxpayer support or wider economic disruption;

- Making derivatives markets safer through the reporting of all overthe-counter ("OTC") derivatives to trade repositories, clearing of all standardized contracts through central counterparties and trading of those contracts (where appropriate) on exchanges or electronic platforms, and subjecting non-centrally cleared contracts to higher capital and minimum margining requirements; and

- Transforming shadow banking into resilient market-based finance through strengthening oversight and regulation of the shadow banking system. ${ }^{8}$

At the Pittsburgh summit in 2009, the G20 leaders committed to strengthen regulatory oversight of OTC derivatives markets, including committing to implement requirements in relation to mandatory clearing through central counterparties, reporting to trade repositories, and, where appropriate, trading on exchanges or electronic trading platforms. ${ }^{9}$ In November 2011, in Cannes, the G20 leaders called on the Basel Committee on Banking Supervision ("BCBS") and the International Organization

7. University of Toronto, G20 Research Group, Common Principles for Reform of Financial Markets, in Declaration of the Summit on Financial Markets and the World ECONOMY (Nov. 15, 2008), http://www.g20.utoronto.ca/2008/2008declaration1115.html.

8. University of Toronto, G20 Research Group, Strengthening the International Financial Regulatory System, in G20 Leaders Statement: The PittsBurgh Summit (Sep. 24-25, 2009), http://www.g20.utoronto.ca/2009/2009communique0925.html\#system.

9. Id. 
for Securities Commission ("IOSCO"), together with other relevant organizations, to develop, for consultation, standards on margining for noncentrally cleared OTC derivatives. ${ }^{10}$ Following these G20 commitments, the G20 countries have introduced new substantive requirements applicable to OTC derivatives which have impacted certain foreign exchange products and market participants. ${ }^{11}$

Following the well-publicized investigations and enforcement actions in 2013 regarding the manipulation of major interest rate benchmarks such as LIBOR by regulatory bodies in several major jurisdictions including the Commodities Futures Trading Commission ("CFTC") in the U.S., the Financial Services Authority ("FSA") in the United Kingdom ("U.K."), and the Japan Financial Services Agency in Japan, IOSCO published its Principles for Financial Benchmarks in July 2013. ${ }^{12}$ The IOSCO Principles provided voluntary guidelines for global administrators on governance, methodology, and accountability. ${ }^{13}$ The Principles were endorsed by the G20 Leaders at their Saint Petersburg Summit in September 2013 as global standards for financial benchmarks and have served as guidance to numerous jurisdictions. The EU was among the first jurisdictions to impose a comprehensive, legally binding regulatory regime governing financial benchmarks. ${ }^{14}$ In June 2013, the Financial Stability Board ("FSB") established an Official Sector Steering Group ("OSSG") of regulators and central banks on interest rate benchmark reform to recommend global standards for reference rate benchmarks and review them against these standards. In February 2014, the FSB agreed to extend its work on financial benchmarks to cover global foreign exchange benchmarks and created the Foreign Exchange Benchmarks Group as a new OSSG subgroup to undertake a review of major foreign exchange benchmarks including their definitions, construction and governance, as well as an analysis of market characteristics around

10. University of Toronto, G20 Research Group, Building Our Common Future: Renewed Collective Action for the Benefit of All, in CANNES Summit Final Declaration (Nov. 4, 2011), http://www.g20.utoronto.ca/2011/2011-cannes-declaration-111104-en.html.

11. See infra, Part III.

12. Press Release, International Organization of Securities Commissions (IOSCO), IOSCO publishes Principles for Financial Benchmarks (July 17, 2013) (on file with IOSCO).

13. See generally BD. OF THE INT'L ORG. OF SEC. COMmissions, Principals for Financial Benchmarks: Final Report, (July 2013), http://www.iosco.org/library/pubdocs/pdf/IOSCOPD415.pdf (providing IOSCO's Principles for Financial Benchmarks).

14. See infra Part III. 
benchmark fixings. ${ }^{15}$ In September 2014, this subgroup issued a report with fifteen recommendations, many of which have been incorporated in the market's first global code of conduct. ${ }^{16}$

During the 2013-2015 timeframe, a number of scandals in the spot foreign exchange market emerged. Certain bank dealers were found to have failed to manage risks around confidentiality, conflicts of interest, and trading conduct in the G10 spot foreign exchange market. This conduct led to enforcement actions from the U.K. Financial Conduct Authority ("FCA"), the Swiss Financial Market Supervisory Authority, and U.S. CFTC and Federal Reserve, among others. These enforcement actions centered on conduct involving the sharing of information about clients' activities and attempted manipulation of G10 spot foreign exchange rates involving collusion among traders at several different firms in a manner which disadvantaged clients and the market. These scandals and the regulatory response were the drivers of the development of the first single code for the global foreign exchange market. ${ }^{17}$

Today, notwithstanding the global scale and importance of the global foreign exchange market, no regulator has jurisdiction over the market itself. Rather, in each global financial center, foreign exchange market participants are subject to various domestic laws and regulations relevant to their foreign exchange activity. That said, the legal underpinnings of the global foreign exchange market generally reflect and reinforce its critical global role. International treaty law has established foundational principles dating back to Bretton Woods which restrict the power of countries to limit the role of the global foreign exchange market in facilitating international trade while affording countries more discretion to regulate their role in capital or investment flows. Domestic laws generally operate consistently with these international treaty law principles by lightly regulating spot and forward foreign exchange transactions most commonly associated with trade, while more rigorously overseeing currency swaps, options, and other foreign exchange derivatives, which are frequently utilized for investment purposes as well. Foreign exchange market participants routinely enter into master trading agreements to establish a contractual framework to govern the foreign exchange transactions between them. Global and national codes of conduct for foreign

15. Press Release, Financial Stability Board to Review Foreign Exchange Benchmarks (Feb. 14, 2014), http://www.fsb.org/wp-content/uploads/pr_140213.pdf).

16. See infra Part VI.

17. See infra Part V. 
exchange market participants provide best practices to promote orderly and fair markets. Together, this tapestry represents the legal underpinnings of the global foreign exchange market.

This Article addresses the legal underpinnings of the OTC wholesale or institutional global foreign exchange market and does not focus on exchange traded foreign exchange futures and related products or the retail segment of the market (foreign exchange is sometimes referred to in this article as "FX"). Part II provides an overview of the global foreign exchange market. ${ }^{18}$ Part III reviews the sources of law underpinning the global foreign exchange market, including international treaty law and the laws of several of the most economically important countries or regions, namely the EU, U.S., and mainland China. ${ }^{19}$ Part IV describes the types and terms of market standard foreign exchange master agreements entered into by market participants. ${ }^{20}$ Part $\mathrm{V}$ examines the best market practices established historically by national codes as well as by the new global code. ${ }^{21}$

\section{The Global Foreign EXChange MARKET}

Foreign exchange trading takes place between global banks, central banks, speculators such as hedge funds, investment managers, commercial entities involved in imports and exports, and retail brokers. Activity in the global foreign exchange market spans seven days a week, twenty-four hours per day, and takes place in various financial centers around the world. In these centers, their business hours overlap and as certain centers close, others open for trading following the sun around the earth. Each day foreign exchange trading starts with the opening of the markets in Australia and New Zealand, followed by Europe, and then North America. It is considered an OTC or interbank market because transactions occur between two counterparties over the telephone or via an electronic network rather than in a centralized manner on an organized exchange like the futures or stock markets.

The Bank for International Settlements ("BIS") Triennial Central Bank Survey is the most comprehensive source of information on the size and structure of global foreign exchange market. The most recent BIS

18. See infra Part II.

19. See infra Part III.

20. See infra Part IV.

21. See infra Part V. 
survey of turnover took place in April 2016. Central banks and other authorities in fifty-two jurisdictions collected data from about 1,300 banks and other dealers in their jurisdictions and reported national aggregates to the BIS, which then calculated global aggregates. ${ }^{22}$

\section{SOURCES OF LAW UNDERPINNING THE GLOBAL FOREIGN EXCHANGE}

22. See BANK For InT'L SETtLEMENTS, supra note 2. Highlights of the survey included:

(1) Trading in foreign exchange markets averaged $\$ 5.1$ trillion per day in April 2016. (2) For first time since 2001, spot turnover declined. Spot transactions fell to \$1.7 trillion per day in April 2016 from \$2.0 trillion in 2013. Spot transactions' share in turnover decreased five percentage points to $33 \%$. In contrast, the turnover of FX swaps increased further, reaching \$2.4 trillion per day in April 2016. This rise was driven in large part by increased trading of FX swaps involving yen. FX swaps remained the most traded instrument, with their share in turnover rising five percentage points to $47 \%$. (3) The U.S. dollar remained the dominant currency, being on one side of $88 \%$ of all trades in April 2016. The euro, yen, and Australian dollar all lost market share. In contrast, many emerging market currencies increased their share. The Chinese renminbi ("RMB") doubled its share to $4 \%$ to become the world's eighth most actively traded currency and the most actively traded emerging market currency, overtaking the Mexican peso. The rise in the share of RMB was primarily due to the increase in trading against the U.S. dollar. In April 2016 , as much as $95 \%$ of RMB trading volume was against the U.S. dollar. (4) The share of trading between reporting dealers grew over the three-year period, accounting for $42 \%$ of turnover in April 2016, compared with 39\% in April 2013. Banks other than reporting dealers accounted for a further $22 \%$ of turnover. Institutional investors were the third largest group of counterparties in foreign exchange markets, at $16 \%$. Trading with non-financial counterparties such as corporations, government entities and individuals accounted for $7.5 \%$ of turnover. (5) In April 2016, sales desks in five countries - the UK, the US, Singapore, Hong Kong SAR, and Japan - intermediated $77 \%$ of foreign exchange trading, up from 75\% in April 2013 and 71\% in April 2010.

Id. 


\section{MARKET}

\section{A. International Treaties}

There are several international treaties which establish rules about the regulation of the global foreign exchange market by their member states. As a general matter, they make a distinction between the regulation of foreign exchange transactions which serve as the source of payment for current transactions or international trade in goods and services and capital transactions including certain financial transactions. Member states are restricted in their ability to impose currency controls on current transactions absent a severe economic crisis while they have more authority to do so in relation to capital transactions.

\section{International Monetary Fund Articles of Agreement}

The IMF was established and operates pursuant to the IMF Articles of Agreement ("Articles"). The Articles contain a number of provisions which impact the regulation of the global foreign exchange market by IMF member states. IMF member states can impose currency controls to regulate international capital movements ${ }^{23}$ but cannot exercise such controls, without IMF consent, in a manner which will restrict payments for current transactions. ${ }^{24}$ The IMF does not automatically grant such approval but has done so in certain cases when requested by a member state managing a severe economic crisis. For example, in 2008, Iceland did obtain IMF permission, but at about the same time period Ukraine did not.

\section{General Agreement on Trade in Services}

General Agreement on Trade in Services ("GATS") is a treaty of the World Trade Organization ("WTO") which for the first time in 1995 established global rules on the trade in services. GATS also contains rules regarding regulation of the global foreign exchange market by its member states. Paragraph one of Article XI prohibits members from imposing exchange controls on international transfers and payments for

23. Articles of Agreement of the IMF, art. 6, 60 Stat. 1401, 2 U.N.T.S. 39.

24. Id. at art. 8, § Art. VIII §2(a). 
current transactions, ${ }^{25}$ but paragraph two of Article XI allows controls in accordance with the IMF Articles and GATS Article XII; ${ }^{26}$ the latter permits controls if a member faces serious balance of payments or external difficulties. $^{27}$

\section{European Union Treaty}

Article 63 of the Treaty on the Functioning of the EU ("TFEU") prohibits all restrictions on movement of capital and payments between member states and non-EU countries. ${ }^{28}$ Article 144(1) allows members outside of the Eurozone to take protective measures if faced with a sudden crisis in its balance of payments although the EU Council and EU Commission retain powers to suspend or impose conditions. ${ }^{29}$ Article 65(1)(b) of TFEU provides that Article 63 is without prejudice to the right of EU member states to "take measures which are justified on grounds of public policy or public security." 30 Article 66 of TFEU authorizes the EU to impose capital controls vis-a-vis non-EU countries for up to six months. ${ }^{31}$

\section{B. National Laws and Regulations}

\section{European Union Regulation}

MiFID II entered into force on January 3, 2018, and is primarily aimed at creating greater market transparency and increasing investor protection. The original version of MiFID, the Markets in Financial Instruments Directive 2004/39/EC (MiFID), was adopted in 2004 as the cornerstone of the EU's Financial Services Action Plan; a project to create a single European market in financial services. MiFID was intended to create a level playing-field for firms to compete in the EU's financial markets and to ensure a consistent level of consumer protection across

25. General Agreement on Trade in Services art. 11, I 2, Apr. 15, 1994, Marrakesh Agreement Establishing the World Trade Organization, Annex 1B, 1869 U.N.T.S. 219.

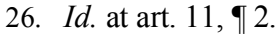

27. Id.

28. Consolidated Version of the Treaty on the Functioning of the European Union art. 63, Dec. 13, 2007, 2012 O.J. (C 326) 71 [hereinafter TFEU].

29. Id. at art. 144(1).

30. Id. at art. 65(1)(b).

31. Id. at art. 66 . 
the EU. However, the pace of technological change, innovation in financial instruments and markets and increased fragmentation in markets and data, combined with calls for reform following the 2008 financial crisis, led to a new legislative package to replace the MiFID regime. The revision of MiFID comprises two framework texts: (1) MiFID II, a directive requiring national transposition, ${ }^{32}$ and (2) MiFIR, a regulation that is directly applicable. ${ }^{33}$ These framework texts are supplemented by various delegated acts which set out most of the technical details and substantive obligations. "The revision primarily aims to create greater market transparency (partly by redressing the unintended consequences of MiFID, such as fragmentation of the trading environment and dark trading) and to increase investor protection." 34

"The provisions of MiFID II include harmonized rules on the authorization and supervision of investment firms, an EU-passport regime for investment firms, rules on the conduct of business, investor protection, market transparency, and the functioning of trading platforms. ${ }^{, 35}$ It applies "to a broad range of financial services firms providing investment services in the EU, including investment firms, market operators, and data reporting services providers" as well as "other financial entities engaging in the provision of investment services, such as banks, insurers, and asset managers." 36

The regulated activities that MiFID II encompasses are broad and are divided into investment services and ancillary services ${ }^{37}$ Execution of orders, trading on own account, reception and transmission of orders, investment advice, and selling financial instruments and investment products, as well as individual portfolio management are considered investment services. ${ }^{38}$ Ancillary services include custody and safekeeping of assets. $^{39}$

MiFID II applies to a wide range of financial instruments including all securities credited to securities accounts and virtually all types of

32. Council Directive 2014/65, 2014 O.J. (L 173) 2, 349) (EU).

33. Commission Regulation 600/2014, 2014 O.J. (L 173) 1, 84) (EU).

34. Markets in Financial Instruments Directive (MiFID II) - Regulation Memo, BNP Paribas: Sec. Securities Servs. (Mar. 21, 2018) https://securities.bnpparibas.com/en_CH/insights/mifid-ii-regulation-memo-2018.html.

35. Id.

36. Id.

37. Id.

38. Id.

39. Id. 
derivative contracts, as well as structured deposits. The foreign exchange instruments within the scope of MiFID II include: deliverable and nondeliverable FX forwards and swaps, FX options, and other FX derivatives. The European Commission ("EC") has determined that FX forwards are outside the scope of MiFID II if they satisfy all of the following conditions: (1) the contract for deliverable FX is physically settled; (2) at least one of the parties to the contract is a non-financial counterparty; (3) the purpose of the contract is to facilitate payment for identifiable goods, services or direct investment; and (4) the contract is not traded on a trading venue. ${ }^{40}$ In contrast, the delegated acts confirm that balance sheet hedging instruments such as non-deliverable FX forwards, FX options, and currency swaps are regulated products. This is because, typically, their purpose is not to facilitate payment for goods and services. ${ }^{41}$ Consequently, these instruments are within scope of MiFID regulation. Spot FX is not covered by the regulation, as it is not considered to be a financial instrument by the European Securities and Markets Authority ("ESMA"), the EU regulator. The EC has been prescriptive in the settlement periods that are to apply to spot FX contracts by distinguishing between "major" and "minor" currencies. The major currencies include the U.S. dollar, the euro, the yen, and the pound, among others. ${ }^{42}$ Contracts involving major currency pairs are to be settled within two trading days. ${ }^{43}$ The settlement period stipulated for contracts involving a minor currency is longer than two trading days; being the period generally accepted in the market for that currency pair. ${ }^{44}$

The key MiFID II requirements include:

40. Commission Regulation 2017/565, 2017 O.J. (L 87) 1, 2, ๆ 10.

41. Recital 13 notes that neither an option nor a swap could be regarded as a spot contract or as a means of payment. $I d$. at $3, \uparrow 13$.

42. The full list of major currencies includes the U.S. dollar ("USD”), euro ("EUR"), Japanese yen ("JPY"), pound sterling "(GBP"), Australian dollar (“AUD”), Swiss franc ("CHF"), Canadian dollar ("CAD”), Hong Kong dollar ("HKD"), Swedish krona ("SEK"), New Zealand dollar ("NZD"), Singapore dollar ("SGD”), Norwegian krone ("NOK"), Mexican peso ("MXN"), Croatian kuna ("HRK"), Bulgarian lev ("BGN"), Czech koruna ("CZK"), Danish krone ("DKK"), Hungarian forint ("HUF"), Polish złoty ("PLN"), and Romanian leu ("RON").

43. Markets in Financial Instruments Directive (MiFID II) - Regulation Memo, BNP Paribas: Sec. Securities Servs. (Mar. 21, 2018) https://securities.bnpparibas.com/en_CH/insights/mifid-ii-regulation-memo-2018.html.

44. Id. 
- Transparency reporting: Firms will need to publicly report executed trades through an Approved Publication Arrangement.

- Transaction reporting: MiFID II extends transaction reporting requirements to all financial instruments traded in the EU, which will need to be reported to approved reporting mechanisms or the client's National Competent Authority.

- Best execution: Under MiFID II investment firms will be required to take all sufficient steps to obtain, when executing orders, the best possible result for their clients - taking into account price, costs, speed, likelihood of execution and settlement, size, nature, or any other relevant consideration.

- Recordkeeping: MiFID II requires firms to keep extensive records of all transactions, communications, services, and activities for ten years, in order for them to be able to provide transparency into the trade life-cycle. This is to support trade reconstruction if required. ${ }^{45}$

The European Market Infrastructure Regulation ("EMIR") "sets out requirements for the clearing of OTC derivatives through authorized central counterparties (“CCP”), collateral exchange, and risk mitigation requirements for non-cleared derivatives, as well as post-trade reporting requirements for all derivatives." ${ }^{46}$ It was adopted on July 4, 2012, and took effect in all EU Member States on August 16, 2012. It implemented the G20 commitment to have all standardized OTC derivatives cleared through a central counterparty in the EU by the end of 2012. ${ }^{47}$ The primary requirements of EMIR are: (a) "[m]andatory central clearing of certain classes of OTC derivatives entered into between certain types of counterpart[ies];" OTC derivatives between certain types of counterpart[ies];" ${ }^{49}$ (c) reporting of all derivatives (including modifications and terminations) to authorized trade repositories including the type of contract, price, settlement

45. Id.

46. James Coiley et al., Ashurst LLP, EMIR: What you NeEd to KNOW, https://www.ashurst.com/en/news-and-insights/hubs/finance-hub/emir/what-you-need-toknow/ (last visited Jan. 15, 2019).

47. Jonathan Herbst \& Hannah Meakin, Norton Rose Fulbright LLP, European MARKET InFRASTRUCtURE REgUlATION: WHAT YOU NEED TO KNOW (Feb. 2012), http://www.nortonrosefulbright.com/knowledge/publications/62449/european-market-infrastructure-regulation-what-you-need-to-know.

48. CoILEy, supra note 47.

49. COILEY, supra note 47. 
date, parties to the contract, and maturity; and (d) "[c]ertain other risk mitigation requirements." 50

For the purpose of EMIR clearing and margining requirements, "OTC derivatives" are derivative contracts not executed on a regulated market. ${ }^{51}$ A "regulated market" for this purpose is a market authorized under MiFID, or a third-country market considered equivalent for the purposes of MiFID (such as markets designated by the CFTC as contract markets in the U.S.). ${ }^{52}$ A "derivative" is defined by reference to the meaning under MiFID which broadly includes swaps, futures, options, and forwards in each case where the underlying is a financial instrument, currency, rate or index, whether settled physically or in cash, or commodities if settled in cash (or physically settled in certain circumstances), credit derivatives, climate and emissions derivatives which can be settled in cash, and financial contracts for difference. ${ }^{53}$

Spot foreign exchange transactions are outside the scope of EMIR. The EC adopted a Delegated Regulation effective January 3, 2018, which provides that spot foreign exchange is generally limited to transactions which settle in $\mathrm{T}+2$ or less (or the longer settlement cycles specified for minor currencies or in connection with hedging a sale or purchase of securities). ${ }^{54}$ The EC has also confirmed that "rolling spot FX" are MiFID derivatives and, therefore, are derivatives for the purposes of EMIR. In its Q\&A, the EC states that: "As opposed to spot trading where there is immediate delivery, a rolling spot FX contract can be indefinitely renewed and no currency is actually delivered until a party affirmatively closes out its position." ${ }^{, 5}$ The Commission went on to conclude that "rolling spot foreign exchange contracts are a type of derivative contract ([i.e.,] either a forward or a financial contract for difference) relating to currencies and are considered financial instruments as defined under MiFID.. ${ }^{, 56}$ The Delegated Regulation also says that a contract shall not be considered an exempt spot FX contract if (irrespective of its explicit terms) there is an understanding between the parties to the contract that delivery of the underlying is to be postponed and not to be performed

50. COILEY, supra note 47.

51. Commission Council Regulation 648/2012, art. 2, ๆ 7, 2012 O.J. (L 201) 15.

52. Council Directive 2014/65/EU, art. 4(1), \ 21, 2014 O.J. (L 173) 382.

53. Commission Council Regulation 648/2012, art. 2, 9甲 5-7, 2012 O.J. (L 201) 15.

54. Council Directive 2014/65/EU, 2014 O.J. (L 173).

55. Guidance on the Implementation and Interpretation of Directive 2004/39/EC: Questions and Answers Published by the Commission, 47 (European Commission).

56. Id. 
within $\mathrm{T}+2$ (or the longer settlement cycles specified in the Delegated Regulation for minor currencies or in connection with hedging a sale or purchase of securities). ${ }^{57}$

On November 24, 2017, the European Supervisory Authorities ("ESA") issued a statement acknowledging the challenges faced by certain end-user counterparties to physically settled FX forwards to exchange variation margin by the scheduled January 3, 2018 deadline. ${ }^{58}$ The ESA acknowledged that: the EU rules developed by the BCBS and IOSCO for the margining of physically-settled FX forwards were based on international standards and that they were being applied on a more limited basis via supervisory guidance in other key jurisdictions. ${ }^{59}$ As a result, the ESA announced that they were undertaking a review of these rules in order to align them with the supervisory guidance in other key jurisdictions. The ESA stated that in order to address these challenges faced by certain end-users, they expected “...competent authorities to generally apply their risk-based supervisory powers in their day-to-day enforcement of applicable legislation in a proportionate manner." 60

On December 18, 2017, the ESA published a draft regulation ("Draft RTS") amending Delegated Regulation (EU) 2016/2251 with the intention of leveling the playing field between EU and non-EU entities when it comes to physically settled FX forwards. ${ }^{61}$ Specifically, the ESA suggested limiting the requirement so that the only variation margin that is required to be exchanged are those for physically settled FX forward transactions entered into: (1) with "institutions" within the meaning of the Capital Requirements Regulation (i.e., credit institutions and investment firms), or (2) with an equivalent entity located in a third country

57. Id.

58. Phillan Amin, White \& Case LlP, Variation Margin Requirements for Physically SeTtled FX Forwards - EMIR Update (June 1, 2018), https://www.whitecase.com/publications/article/variation-margin-requirements-physically-settled-fx-forwardsemir-update.

59. Id.

60. Id.

61. Amin, supra note 59; CoILEY, supra note 47; see Draft Regulatory Technical Standards on Amending Delegated Regulation (EU) 2016/2251 Supplementing Regulation (EU) No 648/2012 of the European Parliament and of the Council with Regard to Regulatory Technical Standards on Risk-Mitigation Techniques for OTC Derivative Contracts Not Cleared by a CCP Under Article 11(15) of Regulation (EU) No 648/2012 with Regard to Physically Settled Foreign Exchange Forwards, at 3, 10-11, COM (2017) 79 (Dec. 18, 2017), https://eba.europa.eu/documents/10180/2065831/Joint+Draft+RTS+on+margin+requirements+for+noncentrally+cleared+OTC+derivatives+\%28JC-2017-79\%29.pdf [hereinafter Draft RTS]. 
that, if it were located in the EU, would meet the definition of institution. $^{62}$

While it is not clear when the Draft RTS will become effective, the statement from the ESA has provided practical relief to commercial FX market participants. ${ }^{63}$ Should the Draft RTS be implemented in its current form, it should have the effect of leveling the playing field with other key jurisdictions. ${ }^{64}$

The EU Benchmarks Regulation ("EU BMR") was created due to concerns about the accuracy and integrity of indices used as benchmarks in financial markets following the imposition of several large LIBOR fines in 2013 and as further concerns were emerging about the integrity of foreign exchange and commodities benchmarks. The EU BMR implements and builds upon the global standards set out in the IOSCO Principles for Financial Benchmarks, which were published in July 2013. The EU BMR became effective on June 30, 2016, with certain provisions relating to critical benchmarks being immediately effective, while most of the provisions did not come into effect until January 1, $2018 .^{65}$

The EU BMR introduces a common framework to "ensure[] the accuracy and integrity of [indices used as] benchmarks" $" 66$ in the EU. The EU BMR applies to the: (a) provision of benchmarks, (b) contribution of input data to a benchmark, and (c) use of a benchmark within the EU. ${ }^{67}$ Under the EU BMR, only the following types of benchmarks may be used by supervised entities within the EU:

a. Benchmarks that are provided by EU based administrators who have been granted authorization or registration under the EU BMR and who are identified on the register to be maintained by ESMA;

b. Benchmarks that have been entered onto the ESMA register which are provided by third country

62. Draft RTS, supra note 62, at 3, 10-11; AMIN, supra note 59.

63. AMIN, supra note 59.

64. AMIN, supra note 59.

65. European Securities and Markets Authority, Policy ACtivities: BENCHMARKS, https://www.esma.europa.eu/policy-rules/benchmarks (last visited Jan. 16, 2019).

66. Id.

67. Id.; EUROPEAN SECURITIES AND MARKETS AUTHORITY, QUESTIONS AND ANSWERS ON THE BENCHMARKS REgUlATION (BMR), ESMA70-145-11, 8. (Jan. 30, 2019), https://www.esma.europa.eu/sites/default/files/library/esma70-145-114_qas_on_bmr.pdf [hereinafter ESMA]. 
administrators who have either: (i) satisfied the requirements for equivalence, (ii) acquired recognition under the EU BMR, or (iii) successfully sought endorsement from an EU authorized or registered administrator or other supervised entity for specific benchmarks. $^{68}$

\section{U.S. Regulation}

Historically, the foreign exchange market has been lightly regulated in the U.S. commencing with the Commodity Futures Trading Commission Act of 1974 which created the CFTC. Pursuant to the so-called Treasury Amendment, transactions involving foreign exchange which were not "for future delivery conducted on a board of trade" were excluded from the Commodity Exchange Act ("CEA"). ${ }^{69}$ This was interpreted to broadly exclude from CFTC jurisdiction OTC FX transactions between banks and other institutional market participants while the CFTC retained jurisdiction over retail $\mathrm{FX}$ transactions.

In 2000, Congress enacted the Commodity Futures Modernization Act to provide the CFTC with clearer jurisdiction over the retail FX market while continuing to exclude the OTC institutional FX market. Retail FX transactions were required to be conducted by regulated entities such as banks, futures commission merchants, and broker-dealers while OTC transactions between "eligible contract participants" ("ECP") were largely exempted.

Following the financial crisis of 2008 and the G20 commitments in relation to regulatory reform of the OTC derivatives markets, comprehensive regulation of the OTC derivatives market was introduced by Title VII of the Dodd-Frank Act ("Dodd-Frank") in 2010. ${ }^{70}$ Specifically, Dodd-Frank introduced the regulation of "swaps" which includes many types of FX transactions such as cash settled forwards, currency options, and currency and cross-currency swaps, but excludes spot FX and physically settled forwards and FX swaps. ${ }^{71}$ Title VII also perpetuated the divide between the institutional and retail markets. The institutional market

68. ESMA, supra note 68 .

69. 7 U.S.C. $\S 2$ (ii) (2012).

70. Dodd-Frank Wall Street Reform and Consumer Protection Act (Dodd-Frank), §§ 724(c), 731, 7 U.S.C $\S 6 s(2012)$.

71. Id. 
is composed of transactions between ECPs; non ECPs are prohibited from entering into swaps unless they are entered into on or subject to the rules of a designated contract market (i.e., a CFTC regulated exchange) or with a federally regulated entity pursuant to a new set of regulations issued by each of the federal regulators. ${ }^{72}$ For the first time, the institutional market became highly regulated requiring dealers to register with the CFTC as swap dealers and comply with business conduct rules, trading documentation requirements, record keeping rules, and margin requirements. ${ }^{73}$ All institutional swap market participants also became subject to mandatory clearing, execution, and reporting (including real-time public reporting) requirements. ${ }^{74} \mathrm{FX}$ transactions have not been subject to the clearing or trading requirements, although the CFTC has considered imposing a clearing requirement on non-deliverable forwards, but has not acted on it to date. ${ }^{75}$ Swap dealers are required to collect and post margin in connection with swap transactions with other dealers and financial end-users such as funds and insurance companies but not generally with non-financial end-users and certain classes of exempt entities. ${ }^{76}$ These include variation and initial margin rules which are being phased in from September 2016 through September 2020 depending on the level of swap activity engaged in by market participants. ${ }^{77} \mathrm{FX}$ transactions exempt from swap regulation are not subject to these margin requirements. In 2013, the Board of Governors of the Federal Reserve System ("Federal Reserve") issued a supervisory letter suggesting that banks subject to their regulation should collect margin on such exempt FX transactions with "financial institutions."78 Physically settled FX forwards and FX swaps are subject to the business conduct and trading documentation rules applicable to swap dealers and reporting requirements (but not the public reporting requirements) applicable to all market participants. Spot FX

72. Id.

73. See generally 7 U.S.C $\S 6 s$ (2012) ("Registration and regulation of swap dealers and major swap participants.").

74. $I d$.

75. David Aron, P. Georgia Bullitt, \& Jed Doench, Regulation of U.S. Currency Transactions, 37 J. ON THE L. Of InV. \& Risk Mgmt. Products: Futures AND Derivatives L. ReP. $1,9 \mathrm{http} / / /$ fia.org/articles/fiaspecial-report-cftc-examines-fx-clearing-mandate.

76. 7 U.S.C $\S 6 \mathrm{~s}(\mathrm{e})(2012)$.

77. Aron, supra note 76.

78. To the Officer in Charge of Supervision at Each Reserve Bank and to Domestic and Foreign Large Financial Institutions by the Federal Reserve from the Board of Governors of the Federal Reserve, Docket No. SR 13-24, (Dec. 23, 2013). 
transactions are not swaps and, therefore, are largely unregulated but remain subject to the CFTC's anti-manipulation authority under the CEA.

On December 10, 2013, the Federal Reserve, the Office of the Comptroller of the Currency ("OCC"), the Federal Deposit Insurance Corporation ("FDIC"), the Securities and Exchange Commission ("SEC") and the CFTC approved a final rule ("Final Rule") implementing Section 619 of Dodd-Frank, commonly referred to as the "Volcker Rule." T9 The Volcker Rule imposed broad prohibitions and restrictions on proprietary trading and investing in, sponsoring, or certain other relationships with, certain types of private funds such as hedge funds and private equity funds by banking organizations and their affiliates. The restrictions on proprietary trading apply to transactions entered into by "banking entities" in "financial instruments" which includes a broad range of securities, derivatives, and commodity futures instruments. ${ }^{80}$

In terms of FX transactions, they are generally subject to the proprietary trading restrictions other than spot FX transactions. There are several exemptions and exclusions which allow banking entities to continue to enter into covered FX transactions, such as the so-called market making and risk mitigating hedging exemptions and the trading on behalf of customers exclusion. ${ }^{81}$ The net effect of the Volcker Rule is to continue to permit banking entities to enter into client driven and hedging FX transactions and prohibit banking entities from otherwise taking proprietary positions in FX. The rule applies globally to "banking entities" covering US insured depository institutions (and their controlling companies and affiliates) as well as foreign banking organizations operating a branch, an agency, or a commercial lending company in the U.S. The Final Rules, however, permit the trading activities of foreign banking entities "solely outside . . . the United States." ${ }^{\text {" }}$ The prohibition on proprietary trading does not apply to the purchase or sale of any financial instrument if a foreign banking entity engaging as principal in the transaction is not located in the U.S. or organized under the laws of the U.S. ${ }^{83}$ Additionally, the transaction must not be booked either directly or on a consolidated basis by any branch or affiliate that is located in the

79. Dodd-Frank $\S 619,12$ U.S.C. $\S 1851$; 12 C.F.R. $\S 248$ (2018).

80. 12 C.F.R. $\S 248.3(\mathrm{a})$ (2018).

81. 12 C.F.R. $\S 248.13$ (2018).

82. Id. $\S(\mathrm{b})(1)(\mathrm{iv})$.

83. Id. $\S(\mathrm{b})(2)(\mathrm{ii})(\mathrm{B})$. 
U.S. or organized under US law. ${ }^{84}$ Importantly, to benefit from the exemption, the counterparty to the transaction must not be a US entity except for foreign operations of a US entity with no U.S.-based staff being involved in the transaction.

\section{Chinese Regulation}

In mainland China, cross-border foreign exchange transactions are subject to foreign exchange controls and all foreign exchange derivative transactions are subject to certain substantive regulations.

In the Chinese foreign exchange system, all foreign exchange transactions involving a cross-border element are regulated ${ }^{85}$ and classified into two categories: capital account items and current account items. As described more fully below, capital transactions are subject to strict capital controls which restrict the convertibility of the Chinese currency, RMB. As a result, RMB trades in the domestic Chinese market within central bank established exchange rate bands as well in an offshore market outside of China.

China's current foreign exchange control system was first introduced in 1996 but today the 2008 Foreign Exchange Administration Regulations are the primary source of regulation for the Chinese foreign exchange control system. The principal bodies responsible for regulating the foreign exchange market are the State Administration for Foreign Exchange ("SAFE") and the People's Bank of China ("PBOC"). SAFE is the administrative agency charged with overseeing foreign exchange activities in China including the issuance of relevant regulations. The Administrator of SAFE also serves as the Deputy Governor of the PBOC. The approval of, or the filing of records with, SAFE is required for a range of transactions involving cross-border foreign exchange payments. SAFE has designated certain commercial banks to undertake settlement and exchange of foreign exchange transactions. ${ }^{86}$ These designated banks may process permitted transactions without SAFE approval in

84. Id. $\S(\mathrm{b})(4)(\mathrm{iv})$.

85. Foreign Exchange Control Regulations of the People's Republic of China (promulgated by the St. Council, Jan. 29, 1996, amended Jan. 14, 1997, re-amended Aug. 1, 2008, effective Aug. 1, 2008), No. 532, chs. 2, 3 (China) http://www.fdi.gov.cn/1800000121_39_675_0_7.html [hereinafter China FX Control Regulations].

86. Provisional Regulations on the Management of Settlement, Sales, and Payment of Foreign Exchange (promulgated by the St. Council, Mar. 24, 1994, effective Apr. 1, 1994), ch.1, art. 2 (China) http://en.pkulaw.cn/display.aspx?cgid=954c230ca59e990bbdfb\&lib=law. 
accordance with the operating guidelines directed by SAFE from time to time. ${ }^{87}$ The PBOC is the central bank of China. One of its roles is to maintain and manage China's official foreign exchange reserves and maintain the RMB exchange rate. ${ }^{88}$

Capital account items are capital inflow or outflow transactions including the increase or decrease in a company's capital, foreign direct investment, loans, and securities investments. ${ }^{89}$ Capital account transactions commonly arise out of: (a) inbound investments by foreign investors and outbound investments by Chinese entities, (b) loans extended by foreigners to Chinese entities, and (c) cross-border guarantees. All capital account transactions are strictly controlled and are subject to approval by, or registration with, SAFE. In certain cases, in lieu of SAFE approval, transactions may be processed by, transactions may be designated banks pursuant to a filing and registration requirement established by various SAFE notices and circulars. Since 2011, SAFE has moved in a measured manner to relax the controls over certain types of capital transactions.

Current account items are ordinary recurring business transactions and commonly arise out of: (a) payments and receipts for the sale of goods, (b) the provision of services, (c) payments of royalty, license, franchise, and other intangible property transactions, (d) personal or real property lease transactions, and (e) dividends. Generally, no SAFE approval is required for current account transactions. Businesses can freely convert foreign exchange for current account transactions subject to any required government approval of the underlying transactions. These foreign exchange transactions can be processed by a SAFE designated bank which is required to review the authenticity of the underlying transaction documentation and the payment of all applicable Chinese taxes. ${ }^{90}$

Since 2004, foreign exchange derivative transactions have been subject to certain substantive regulations. China's first regulations on derivatives trading were the Provisional Administrative Rules Governing Derivatives Activities of Financial Institutions (the "2004 Provisional Derivatives Rules"). Promulgated by the China Banking and Regulatory

87. China FX Control Regulations, supra note 86, at ch. 3, art. 21.

88. Law of the People's Republic of China on the People's Bank of China (amended by the Standing Comm. Nat'l People's Cong., Dec. 27, 2003) ch. 1, art. 4, § 5 (China), http://www.npc.gov.cn/englishnpc/Law/2007-12/12/content_1383712.htm.

89. China FX Control Regulations, supra note 86, at ch. 8, art. 52.

90. China's FX Control Regulations, supra note 86, at ch. 3, arts. 21-23. 
Commission ("CBRC"), ${ }^{91}$ they were implemented on March 1, 2004 (amended on 3 July 2007)."92 These rules detailed qualification requirements and required procedures for financial institutions in using financial derivatives to either hedge risks or accommodate clients and included risk management measures. ${ }^{93}$ Derivatives were defined as "financial contracts that derive their values from the prices of one or a number of underlying assets or indices, and that are basically classified as forwards, futures, swaps and options." 94 The definition included "structured financial instruments with the characteristics of forwards, futures, swaps, and options, and various combinations thereof." 95 These rules applied to all types of foreign exchange derivative transactions and did not apply to spot foreign exchange transactions.

On January 5, 2011, the CBRC further revised the 2004 Provisional Derivatives Rules by issuing the Administrative Rules on Derivative Transaction Business of Banking Financial Institutions (the "2011 Administrative Derivative Rules"). ${ }^{96}$ The 2011 Administrative Derivative Rules "apply to derivative transactions entered into by a banking financial institution." 97

Article 4 of the 2011 Administrative Derivative Rules divides derivative transactions into two separate categories according to the underlying purpose of the transaction: hedging and non-hedging. Under Article 4 , hedging transactions are transactions that are "initiated by a [banking financial institution] for the purpose of hedging the exposure (credit, market or liquidity related) arising from its own assets and liabilities." 98 Nonhedging transactions cover: (a) transactions initiated by clients of a

91. Effective April 8, 2018, the CBRC and the China Insurance Regulatory Commission ("CIRC") merged into the China Banking and Insurance Regulatory Commission which assumed the supervisory functions of the CBRC and CIRC.

92. Provisional Administrative Rules Governing Derivatives Activities of Financial Institutions (promulgated by the China Banking and Regulatory Commission., Feb. 4, 2004, effective Mar. 1, 2004) ch. 1, art. 3. (China) http://www.cbrc.gov.cn/EngdocView.do?docID=556 [hereinafter 2004 Provisional Derivative Rules].

93. Catherine Husted, Jane Jiang, \& Yvonne Siew, Allen \& Overy, CBRC Issued THE LONG Awaited Revised DeRIVATIVes Rules (Jan. 31, 2011), http://www.allenovery.com/publications/en-gb/Pages/CBRC-issued-the-long-awaited-revised-derivativesrules.aspx.

94. 2004 Provisional Derivative Rules, supra note 93 at art. 3.

95. 2004 Provisional Derivative Rules, supra note 93 at art. 3.

96. Husted, Jiang, \& SiEW, supra note 94.

97. Husted, JiAnG, \& SieW, supra note 94.

98. HuSTED, JIANG, \& SiEW, supra note 94. 
banking financial institution; ${ }^{99}$ (b) market-making transactions; ${ }^{100}$ and (c) proprietary trades. ${ }^{101}$ Article 4 further requires that hedging-type transactions comply with specific hedge accounting rules. ${ }^{102}$ This requires hedging transactions to be managed on a banking financial institution's own books, while non-hedging transactions are to be managed the institution's trading book. ${ }^{103}$

A banking financial institution's qualification to enter into derivative transactions, pursuant to Article 8 of the 2011 Administrative Derivative Rules, is classified into two types: Basic and Ordinary. Institutions qualifying as Basic are limited to entering only hedging transactions. Ordinary Institutions may enter both hedging and non-hedging transactions. The criteria to obtain an Ordinary-type approval are "substantively similar" to those qualification criteria for the derivative approval under the 2004 Provisional Derivatives Rules. ${ }^{104}$ However, the 2011 Administrative Derivative Rules impose certain additional requirements, including an obligation to separate hedging and non-hedging business. ${ }^{105}$ By contrast, the criteria for obtaining a basic type approval is far less, as they require "no hard criteria for business head and no express requirement for front/middle/back desks."106

Under the 2011 Administrative Derivative Rules, in OTC derivative transactions (including all FX derivative transactions) between a banking financial institution and clients, the banking institution is required to regularly provide clients, which are not financial institutions, with written valuation reports or risk reminder letters delivered by letter, e-mail, fax or any other recordable means, and ensure that the relevant materials are delivered to the client in a timely manner. ${ }^{107}$ Several key

99. These include "any hedging transaction that [a banking financial institution] may enter into with a third party" to hedge a client-facing transaction. HuSTED, JIANG, \& SIEW, supra note 94 .

100. Market-making transactions are those in which a banking financial institution provides quotes and trades in its capacity as a market maker. HuSTED, JIANG, \& SIEW, supra note 94.

101. Proprietary trades are those in which a banking financial institution enters into by using its own funds (rather than a clients) for profit. HuSTED, JiANG, \& SiEW, supra note 94.

102. Husted, JiAnG, \& SiEW, supra note 94.

103. HuSTED, JiANG, \& SiEW, supra note 94.

104. HuSTED, JiANG, \& SiEW, supra note 94.

105. Husted, JiAnG, \& SiEW, supra note 94.

106. Husted, JiANG, \& SiEW, supra note 94.

107. Memorandum from JunZeJun Law Offices for aosphere LLP (Oct. 17, 2018) (on file with aosphere LLP) [hereinafter JunZeJun]; G20 REGULATORY REQUIREMENTS RELATING TO Derivatives Transactions in the People's Republic of China: Summary, AOSPHERE LLP (2018), aosphere Rulefinder G20 [hereinafter G20 REGULATORY REQUIREMENTS]. 
provisions incorporated into the 2011 Administrative Derivative Rules include: "client suitability assessment (Article 44), obtaining specific statement/acknowledgment from clients regarding genuine need and authority to trade derivatives and other aspects (Articles 45 and 52), product description and risk disclosure requirements (Article 48), [and] encouraging the use of basic and simple products (Article 16)."108

In terms of implementing the G20 commitments, China has introduced mandatory trade execution and trade reporting requirements applicable to certain foreign exchange transactions and market participants.

Where mandatory trade execution applies, Chinese incorporated financial institutions ("PRC FIs"), including Chinese branches, must execute in-scope transactions with other PRC FIs via the China Foreign Exchange Trade System \& National Interbank Funding Centre. In scope transactions are:

(1) RMB-FX forward transactions between the members of the interbank RMB-FX forward market; (2) RMB-FX swap transactions between the members of the interbank RMB-FX swap market; (3) RMB-FX option transactions between the members of the interbank RMB-FX option market; and (4) RMB-FX currency swap transactions between the members of the interbank RMB-FX currency swap market (together, RMB FX Derivative Transactions). ${ }^{109}$

If a PRC FI fails to comply with the mandatory trade execution requirement in relation to RMB-FX Derivative Transactions, according to the Interim Rules on the Administration of Interbank Foreign Exchange Market, SAFE may circulate a notice of criticism in respect of the PRC FI, suspend the PRC FI from entering into foreign exchange transactions or cancel the PRC FI's membership of the interbank foreign exchange market. ${ }^{110}$

OTC derivative transactions, including those involving foreign exchange, entered into by PRC FIs have traditionally been required to be reported to their respective regulators. ${ }^{111}$ In May 2017, the Securities

108. HuSTED, JIANG, \& SiEW, supra note 94.

109. G20 REgulatory REQUiREMENTS, supra note 108.

110. JunZeJun, supra note 108; G20 REGULATORY REQUIREMENTS, supra note 108.

111. JunZeJun, supra note 108. 
Association of China issued rules providing that OTC financial derivative transactions entered into by Securities Industry Institutions (i.e., Chinese securities and fund management companies regulated by the China Securities Regulatory Commission ("CSRC")), are to be reported to the OTC securities business reporting system managed by the Chinese Securities Internet Securities Co., Ltd. ${ }^{112}$ Such reporting must occur within five business days of trade execution for all OTC financial derivative transactions other than option transactions which must be reported within one business day. ${ }^{113}$ These reporting requirements apply to all types of foreign exchange derivative transactions executed outside the China Securities Internet System and do not apply to spot foreign exchange transactions. ${ }^{114}$ While these rules are self-regulatory rules for market participants and not technically legal requirements, they were issued with the agreement of the CSRC and, therefore, market participants are incentivized to comply with them. There is no requirement in China to obtain a legal entity identifier or LEI that identifies distinct legal entities that engage in certain financial transactions. ${ }^{115}$

\section{MASTER TRAding AgREEMENTS}

Foreign exchange market participants regularly enter into master trading agreements to establish the contractual framework which will govern the foreign exchange transactions between them. While some master agreements only apply to foreign exchange transactions, others apply to broad classes of trading transactions such as commodity, credit, equity, and rate derivatives transactions as well as foreign exchange transactions. While there are a variety of master agreements, there is a high degree of architectural commonality among them in that they typically constitute an agreement between two parties to govern specified types of transactions between them each to be separately acknowledged by a confirmation; the terms of the master agreement and each confirmation to constitute a single agreement. Common master agreement provisions include: (1) settlement or payment netting, (2) events of default, (3) termination events (e.g., no-fault events such as illegality, force majeure

112. Circular on Further Strengthening the Regulation of OTC Option Business by Securities Companies (issued by the Securities Association of China, May 22, 2017) (China).

113. Id.

114. JunZeJun, supra note 108.

115. JunZeJun, supra note 108. 
or changes in tax laws), (4) close-out netting, (5) set-off, (6) non-reliance, and (7) regulatory provisions.

There are numerous industry sponsored master agreements including: (1) the International Swaps and Derivatives Association Master Agreement and Credit Support Annex, which is a multi-product master agreement; (2) the Foreign Exchange Committee International Foreign Exchange Master Agreement, covering spot and forward foreign exchange transactions, International Currency Options Market Master Agreement covering currency option transactions, and the International Foreign Exchange and Options Master Agreement covering foreign exchange spot, forward, and option transactions, (3) French Banking Federation Master Agreement and Collateral Annex which is a multi-product agreement, (4) Association of German Banks Master Agreement for Financial Derivatives Transactions and Collateral Addendum which is a multi-product master agreement, and (5) National Association of Financial Market Institutional Investors Master Agreement which is mandatory for OTC derivatives transactions linked to currency, rate, bond, credit and gold entered into between participants of China's interbank bond market and Master Agreement of OTC Derivative Transaction in China Securities and Futures Market which is mandatory for certain types of domestic OTC derivatives transactions entered into by Securities Industries Institutions.

\section{CODES OF CONDUCT}

\section{A. Local Market Codes}

Since the 1970s, different codes ("Codes") have been issued by foreign exchange committees and trade associations in jurisdictions with significant FX markets. These Codes typically are voluntary but frequently refer to legal requirements, ordinances or regulations which are binding in applicable jurisdictions.

"The Foreign Exchange Committees in Hong Kong, London, New York, Singapore[,] and Tokyo each produce and maintain their own Codes. The Australian Foreign Exchange Committee and the ECB Foreign Exchange Contact Group, along with a number of other regional groups, endorse the ACI Model Code" 116 issued by the ACI Financial

116. ACI Financial Markets Association, ACI - Influencing Industry Behaviour, Supporting Market Practice, https://acifma.com/about-aci (last visited Jan. 17, 2019). 
Markets Association (“ACI”), "a leading global trade association"117 established in 1955 representing the interests of the professional financial markets community. ${ }^{118}$ The ACI Model Code was "the first industrywide Code of Conduct for the OTC[]FX . . . markets" ${ }^{119}$ which influenced many national Codes. ${ }^{120}$

While the Codes have distinctive features based upon local factors in different parts of the world, there is broad recognition that the foreign exchange market transcends national borders. Accordingly, the various Foreign Exchange Committees around the world have worked together to enhance communication and coordination, share information on Committee initiatives and projects, and to exchange perspectives on developments and trends in the global foreign exchange market. As such, there is a core set of principles which underpin the existing Codes including: (1) "develop and promote a strong culture of ethical behaviour and standards of conduct;"121 (2) "promote awareness and use of general dealing practices, procedures, and conventions;" timely pre-trade preparation and trade capture," 123 (4) "support robust and efficient back office operations including confirmation, netting, payment, and settlement; and"124 (5) "mitigate risk in foreign exchange transactions from the point of initial discussion regarding a potential transaction to settlement." 125

\section{B. FX Global Code}

The global foreign exchange market is regulated on a national or regional basis rather than on a global basis. The spot and forward foreign exchange markets often are outside regulation or lightly regulated. However, during the 2013-2015 timeframe, a number of scandals in the spot

\footnotetext{
117. Id.

118. Id.

119. Id.

120. Global Preamble: Codes of Best Market Practice and Shared Global Principles, CANAdian Foreign EXCH. COMM. (Mar. 30, 2015), https://www.cfec.ca/files/2015/expanded-global-preamble-300315.pdf.

121. Id.

122. Id.

123. Id.

124. Id.

125. Id.
} 
foreign exchange market emerged ${ }^{126}$ which, as discussed above, led to enforcement actions by regulators from several major jurisdictions. These scandals and the regulatory response were the drivers of the development of a single code for the global foreign exchange market.

In May 2015, the BIS formed the Foreign Exchange Working Group ("FXWG") whose membership consisted of central bank and other monetary authorities from sixteen foreign exchange market jurisdictions to develop a global code of conduct in the foreign exchange markets. ${ }^{127}$ To support the FXWG, a Market Participants Group was established consisting of participants from the sell side and buy side of the market as well as FX infrastructure providers to work closely with the FXWG. ${ }^{128}$ In May 2017, the FXWG published the final version of the FX Global Code, comprising 55 principles (organized around six leading principles) of good practice in the wholesale foreign exchange market. ${ }^{129}$ A newly established Global FX Committee ("GFXC") consisting of central bank-sponsored Foreign Exchange Committees and similar structures from sixteen countries and regions was charged with maintaining the FX Global Code. "The [FX Global] Code does not impose binding legal or regulatory obligations on market participants" 130 but it is intended to promote a "robust, fair, liquid, open, and appropriately transparent market."131 That said, a market participant may publicly disclose its commitment to implementing the FX Global Code via a form "Statement of Commitment" confirming that it "has taken appropriate steps, based on the size and complexity of its [FX market activities], and the nature of its engagement in the FX market, to align its [FX market activities] with the principles of the Code."132 Many regulators have issued statements setting out their hopes that there will be widespread adoption of the FX Global Code by

126. See, e.g., Liam Vaughan et al., Traders Said to Rig Currency Rates to Profit Off Clients, BlOOMBERG (June 11, 2013), https://www.bloomberg.com/news/articles/2013-0611/traders-said-to-rig-currency-rates-to-profit-off-clients.

127. David J. Gilberg et al., FX Global Code-Global Principles of Good Practice in the Foreign Exchange Market, Sullivan and Cromwell LlP 1 (June 20, 2017), https://www.sullcrom.com/siteFiles/Publica-

tions/SC_Publication_FX_Global_CodeGlobal_Principles_of_Good_Practice_in_the_Forei gn_Exchänge_Market.pdf.

128. Id.

129. Global Foreign Exchange Committee, FX Global Code: A Set of Global Principles OF GoOd Practice in the Foreign Exchange Market 1 (2018), https://www.globalfxc.org/docs/fx_global.pdf [hereinafter FX GLOBAL CODE].

130. Id. at 1 .

131. Id.

132. Id. at 72 . 
firms. ${ }^{133}$ In connection with the release of the FX Global Code, the BIS also published a Report on Adherence to the FX Global Code indicating that central banks intend to adhere to the FX Global Code consistent with their legal duties or policy functions and will generally expect that their regular foreign exchange trading counterparties adhere to the FX Global Code. The FX Global Code consists of the following six leading principles:

- Ethics: Market participants ${ }^{134}$ are expected to behave in an ethical and professional manner to promote the fairness and integrity of the FX market.

- Governance: Market participants are expected to have a sound and effective governance framework to provide for clear responsibility for and comprehensive oversight of their FX market activity and to promote responsible engagement in the FX market.

- Execution: Market participants are expected to exercise care when negotiating and executing transactions in order to promote a robust, fair, open, liquid, and appropriately transparent FX market.

- Information Sharing: Market participants are expected to be clear and accurate in their communications and to protect confidential information to promote effective communication that supports a robust, fair, open, liquid, and appropriately transparent FX market.

133. See Jason Merritt, The FX Global Code: The EU Shows Support, FineXTRA (May, 31, 2018), https://www.finextra.com/blogposting/15414/the-fx-global-code-the-eu-showssupport (noting increase in adherence to the Global FX Code).

134. A "market participant" is defined as a person or organization (regardless of legal form) that: (i) is active in FX markets as a regular part of its business and is engaged in the activity of the purchase or sale of one currency against another, or in transactions designed to result in gains or losses based upon the change in one or more FX rates, such as derivatives, whether deliverable or non-deliverable, either directly or indirectly through other market participants; or (ii) operates a facility, system, platform, or organization through which participants have the ability to execute the type of transactions described in (i); or (iii) provides FX benchmark execution services; and (iv) is not considered a retail market participant in the relevant jurisdictions. FX GLOBAL CODE, supra note 130, at 3. 
- Risk Management and Compliance: Market participants are expected to promote and maintain a robust control and compliance environment to effectively identify, manage, and report on the risks associated with their engagement in the FX market.

- Confirmation and Settlement Processes: Market participants are expected to put in place robust, efficient, transparent, and risk-mitigating post-trade processes to promote the predictable, smooth, and timely settlement of transactions in the FX market. ${ }^{135}$

The FX Global Code has been broadly endorsed and adopted by central banks, Foreign Exchange Committees, trade associations, and private sector wholesale market participants. The Foreign Exchange Committees have generally endorsed the FX Global Code and are in different stages of replacing or updating their legacy local Codes. In 2017, the ACI announced the retirement of the ACI Model Code with the publication of the FX Global Code. ${ }^{136}$ As a condition of membership, the ACI requires members to accept the principles of behavior and market practice contained in the FX Global Code and has also announced that it will be replacing the Model Code with Further Guidance and Recommended Best Practice advice. ${ }^{137}$ The responses to the publication of the FX Global Code from the official sector in a number of jurisdictions are summarized below.

\section{Australia}

At the May 2017 launch of the FX Global Code in London, Guy Debelle, deputy governor of the Reserve Bank of Australia noted the work undertaken to produce a principles-based code rather than a set of prescriptive regulatory standards. He stated that "[i]t will not impose legal or regulatory obligations on market participants, nor will it supplant

135. FX Global Code, supra note 130, at 2.

136. ACI Financial Markets Association, ACI - Influencing Industry Behaviour, Supporting Market Practice, https://acifma.com/about-aci (last visited Jan. 17, 2019).

137. Id. 
existing regulatory standards or expectations."138 He urged market participants to publicly adopt the FX Global Code by submitting Statements of Commitments and indicated that adherence to the FX Global Code is likely to become a requirement of membership on the Australian Foreign Exchange Committee. ${ }^{139}$ On November 7, 2017, the Reserve Bank of Australia committed to adhering to the FX Global Code when conducting its activities in the foreign exchange market. Furthermore, it informed each of the institutions on its counterparty panel that their trading relationship will cease at the end of May 2018 unless they have provided a statement of commitment.

In May 2017, the Australian Securities and Investments Commission ("ASIC") encouraged Australian market participants to adhere to the standards set out in the FX Global Code in releasing Report 525: Promoting Better Behavior: Spot FX. ${ }^{140}$ Based on ASIC's investigation of the spot foreign exchange market since 2014, the Report 525 highlighted perceived poor conduct of major Australian financial institutions in the wholesale FX market and sets out what ASIC considers to be good practice principles to prevent, detect, and respond to inappropriate practices. ${ }^{141}$ ASIC stated that it will use Report 525 as a reference point for its surveillance of the FX markets.

\section{China}

In May 2017, China announced its intention to create its own version of the FX Global Code for foreign exchange markets in a move aimed at aligning the country's rules with international standards. ${ }^{142}$ The Chinese code will apply to local and foreign banks operating in the Chinese onshore market. The work on the code is led by the recently created Chinese FX Committee which operates under the guidance of the PBOC. In the interim, numerous Chinese financial institutions have committed to the FX Global Code.

138. Guy Debelle, Deputy Governor, Reserve Bank of Austl., Opening Remarks at the Launch of the FX Global Code. (May 25, 2017), https://www.rba.gov.au/speeches/2017/spdg-2017-05-25.html.

139. Id.

140. Austl. Sec. \& Inv. Comm., Promoting Better Behaviour: Spot FX (Report 525)

(May 2017), https://download.asic.gov.au/media/4270050/rep525-published-26-may2017.pdf.

141. Id.

142. China Foreign Exchange Trade System \& Nat'l Interbank Funding Center, GFXC, http://new.chinamoney.com.cn/english/cfxcgfxc/ (last visited Jan. 17, 2019). 


\section{Hong Kong}

On May 25, 2017, the Hong Kong Monetary Authority ("HKMA") issued a statement on the publication of the FX Global Code noting its strong support for the principles of good practice. ${ }^{143}$ The HKMA highlighted the increasing volume of FX activity in Asia and went on to say that it would engage with local market participants to promote adherence to the FX Global Code. ${ }^{144}$ Although the HKMA acknowledged that the FX Global Code is voluntary, the HKMA encouraged market participants to demonstrate their commitment to adherence through the statement of commitment. ${ }^{145}$

\section{United States}

At the launch of the FX Global Code in New York, James Bergin of the Federal Reserve Bank of New York endorsed the FX Global Code and noted that:

[T] he Code is written as principles. The reasons for this are twofold. First, the Code is not regulation. The text is quite clear about the status of the Code as a set of good practice recommendations, a document that is not intended to supplant or modify applicable law or to act as a safe harbor for behavior that contravenes applicable law. In doing so, it recognizes the importance of compliance with the law and the role of authorities in enforcing the law. ${ }^{146}$

Mr. Bergin also noted that the New York Fed, as the sponsor of the New York Foreign Exchange Committee, has determined to link membership on this committee with adherence to the FX Global Code. In May 2018, the New York Fed released its Statement of Commitment to the FX

143. Press Release, Hong Kong Monetary Authority, BOK, HKMA, MAS, RBA and RBI Welcome the Publication of the FX Global Code (May 25, 2017), https://www.hkma.gov.hk/eng/key-information/press-releases/2017/20170525-3.shtml.

144. Id.

145. Id.

146. James P. Bergin, Senior Vice President, Fed. Res. BanK of NY, Panel Opening Remarks at the Forex Network (May 25, 2017), https://www.newyorkfed.org/newsevents/speeches/2017/ber170525. 
Global Code and indicated in a press release that it was "committed to conducting its foreign exchange market activities, when acting as a Market Participant, in a manner consistent with the principles of the Code."147

\section{United Kingdom}

Both the Bank of England and the FCA issued responses to the publication of the FX Global Code. The Bank of England confirmed that the FX Global Code superseded existing guidance in the Bank's non-investment products code. In February 2018, the Bank of England issued a Statement of Commitment to the FX Global Code. ${ }^{148}$ The FCA has linked the FX Global Code to its expectations of senior managers under the Senior Managers and Certification Regime. ${ }^{149}$ The FCA has stated that it expects senior managers, certified persons and other relevant people to be able to demonstrate adherence with the standards of market conduct. ${ }^{150}$ The FCA noted that it knew that firms were already undertaking work on satisfying the principles of the FX Global Code and it hoped that firms would promote adherence to the FX Global Code by expecting their counterparties to similarly adhere to it as it applies to them. ${ }^{151}$

\section{CONCLUSION}

While the legal underpinnings of the modern global foreign exchange market have their origins in the post-war era when the Allied powers entered into the Bretton Woods Agreement in 1944, they have evolved in response to market developments. The foundational principles established at Bretton Woods that the rules governing the global foreign exchange market should not restrict international trade but may limit capital or investment flows survive today. Since the transition to a foreign exchange market based on floating exchange rates in the major

147. Press Release, Fed. Reserve Bank of N.Y., Statement of Commitment to the FX Global Code (May 24, 2018), https://www.newyorkfed.org/markets/opolicy/operatingpolicy 180524.

148. Press Release, Bank of Eng., Statements of Commitment to Market Codes (Feb. 6, 2018), https://www.bankofengland.co.uk/news/2018/february/statements-of-commitmentto-markets-code-of-conduct.

149. Press Release, Fin. Conduct Auth., FCA statement on the publication of the FX Global Code (May 25, 2017), https://www.fca.org.uk/news/statements/fca-statement-publication-fx-global-code.

150. $I d$.

151. Id. 
industrialized democracies in the 1970s, prudential regulation of the major bank foreign exchange dealers and the establishment of industry best market practices in the form of codes of conduct and standard master trading agreements have played an important role in the development of an orderly foreign exchange market. Following the 2008 financial crisis and the high-profile LIBOR manipulation enforcement actions in 2013, substantive regulations were introduced globally led by the G20 member countries. Guided by the foundational principles established at Bretton Woods, the legal underpinnings of the global foreign exchange market are well placed to continue to evolve as market developments dictate while supporting the market's critical role in facilitating international trade and cross-border investment. 